\title{
Aligning design with science: tree grids and rings in the landscape
}

\author{
G.H. Stoffberg1, M.W. van Rooyen², H.T. Groeneveld³ and M.J. van der Linde ${ }^{3}$
}

1Department of Environmental Sciences, Florida, Johannesburg, University of South Africa, South Africa; ${ }^{2}$ Department of Plant Sciences, University of Pretoria, Pretoria, South Africa; ${ }^{3}$ Department of Statistics, University of Pretoria, Pretoria, South Africa.

\begin{abstract}
Tree grids and tree rings pose certain challenges to the designer of landscapes especially designing hard landscapes such as pavements, parking areas and roadsides. One challenge is insufficient knowledge of lateral growth space required by tree stems over time. Inappropriate size selection may cause damage to tree rings, tree grids and trees, resulting in costly repairs and unsightly landscape features. Lack of a rigorous knowledge base may prevent the designer or urban forester from choosing appropriate ring or grid sizes. However, these situations may be prevented or avoided should the choices be based on scientific knowledge of tree stem growth rates. This paper presents the results of an investigation of stem growth rates of three indigenous savannah street trees species growing in the City of Pretoria, Gauteng Province, South Africa. The stem diameters of each species were measured at ground level. Random stratified sampling was conducted, with the total sample size being 282 , the oldest tree being more than 46 years of age. Stem diameter was regressed on tree age to compute estimated stem diameter growth rates. Thereafter comparisons were made to rings found in the local landscape industry. The differences in growth rates showed that Combretum erytrophyllum, Searsia lancea and Searsia pendulina will outgrow small tree grids in approximately $10.75,18.50$, and 15.50 years, respectively. The paper suggests that the statistical analysis and modelling of field data increase certainty for design parameters, enhancing the excellence of urban landscapes and forests.
\end{abstract}

Keywords: allometry, growth rate, stem diameter, street trees, urban forests

\section{INTRODUCTION}

In the design of landscapes trees are used to define space, enhance and facilitate recreation experiences and create landscape genus loci. Trees are vertical design elements in landscape architectural design pallets and stems pronounce columns, pillars, rhythm and anchorage to space. They furthermore provide visual and aesthetic benefits, creating interest in the landscape through seasonal changes, enhancing scenic outdoor recreation and interactional experiences with nature (McPherson et al., 1994; Jorgensen et al., 2002, 2007; Bentsen et al., 2010; Lehmann, 2014; Shackleton et al., 2014).

Trees do not hold only services and benefits, but they also incur costs and disservices to urban environments (McPherson et al., 1994; Nowak and Dwyer, 2007; Soares et al., 2011). Street trees and trees planted in hard landscapes are often protected by tree rings, tree grids or tree grates (apparel). The apparel placed around newly planted trees allows for soil aeration, reduces chances of soil compaction, provides a surface to walk on, facilitates watering and fertilization (Miller, 1997). However, the apparel may become problematic and unsightly because of lateral stem growth that could be obstructed by the inadequate space allocated to the specified apparel (Stoffberg, 2006).

Roy et al. (2012) present an in depth and extensive quantitative literature review of 115 original research papers. In this review 10 papers were identified that related to "tree growth", of these only three papers present research on the theme "predicting diameter, height, crown width, and leaf area of street trees".

McPherson and Peper (2012) present research in which more than 1800 growth 
equations from measurements of 17000 trees in 16 cities have been developed by the USDA Forest Service's reference city research, and include various tree dimensions.

Gaugris et al. (2008) investigated the growth rate of selected woody species in a natural ecosystem in northern Maputaland, KwaZulu-Natal, South Africa. However, the research was conducted on trees that grow outside the urban environment. Research conducted on indigenous urban street tree stem growth rates are also limited in South Africa (Stoffberg, 2006; Stoffberg et al., 2008; Stoffberg and van Rooyen, 2012; De Lacy and Shackleton, 2014).

Fundamental to this paper is that growth rate terminology such as slow, moderate or fast that are often used to describe tree growth are inadequate for landscape designers. In contrast, the aim of this research was to illustrate that applied statistical research could inform landscape designers in everyday studio practice. The alignment is demonstrated through investigating apparel (static) in relation to stem growth (dynamic).

\section{METHODS}

This study was conducted during April-September 2002 in the City of Pretoria, South Africa (Stoffberg, 2006). Stem diameter to age ratios are calculatable when tree age series and correlated stem diameter measurements are known. Allometric calculations are used to model stem diameter lateral growth rate to tree age growth predictions (Stoffberg, 2006; Stoffberg et al., 2008, 2010).

This research is based on allometric growth modelling for the regularly used South African savannah street trees Combretum erythrophyllum (Burch.) Sond. (river bushwillow), Searsia lancea (Lf.) Barkley (karee) and Searsia pendulina (Jacq.) Moffett (white karee) (Stoffberg, 2006; Van Wyk and Van Wyk, 2013).

Stem circumferences were determined with a tape measure at $50 \mathrm{~mm}$ above ground level or just above the basal swelling. Perpendicular stem diameter measurements were taken by calipers to calculate a mean for small trees at the same height. Diameter at breast height (DBH at $1.37 \mathrm{~m}$ above ground level) is often an inappropriate measurement as the African savanna species often branch at lower heights (Stoffberg, 2006). Biased selection of trees, could negatively alter results (Clark and Clark, 2000), and were avoided by stratified random sampling, of streets and trees in the streets.

The majority of the street trees grew in non-irrigated, managed lawn, residential environments and were planted between 1955 and 2001. Tree ages were obtained from the Municipality, aerial photographs and personal communication with botanical and horticultural staff. Tree assessments (Table 1) include two groups of trees from parking lots (Searsia lancea and Searsia pendulina with planting dates of 1970 and 1987, respectively), enabling a wider range of analysis and application (Stoffberg, 2006; Stoffberg et al., 2010).

Several growth models were assessed (Stoffberg, 2006): exponential (Zhang, 1997), first degree logistic (Brewer et al., 1985), Gompertz (du Toit, 1979), Lundqvist (Brewer et al., 1985) and Richards family (du Toit, 1979). A logarithmic equation (Peper et al., 2001a, b) gave the most appropriate fit (Stoffberg, 2006), and was used for calculating the allometric stem diameter growth rates. A detailed description of the methodology can be found elsewhere (Stoffberg, 2006).

Annual growth rate (AGR) (Jalota and Sangha, 2000) was calculated as:

$$
A G R=\frac{a-b}{t}
$$

where "AGR" is the annual growth rate in mm y-1, " $a$ " is the largest stem diameter (mm) reading, " $b$ " is the smallest stem diameter $(\mathrm{mm})$ reading and " $t$ " is the time period between the readings in years. The mean was used to calculate the growth rate of the observed data (Stoffberg, 2006). 
Table 1. The minimum ages (years since planting in the streets), maximum age ranges and stem diameter ranges of which measurements were taken (Stoffberg, 2006).

\begin{tabular}{lccccc}
\hline Species & N & $\begin{array}{c}\text { Minimum age } \\
\text { (years) }\end{array}$ & $\begin{array}{c}\text { Maximum age } \\
\text { (years) }\end{array}$ & $\begin{array}{c}\text { Range } \\
\text { (years) }\end{array}$ & $\begin{array}{c}\text { Stem diameter range } \\
\text { (mm) }\end{array}$ \\
\hline Combretum erythrophyllum & 105 & 1.2 & 47.6 & 46.4 & $26-685$ \\
Searsia lancea & 107 & 1.3 & 32.6 & 31.3 & $26-507$ \\
Searsia pendulina & 70 & 3.4 & 15.6 & 12.2 & $36-352$ \\
\hline
\end{tabular}

\section{RESULTS AND DISCUSSION}

The results presented are quantitative and model stem diameter growth employing statistical methods, derived from measurements of 282 street trees (Stoffberg, 2006). The calculated allometric regression equations enable estimated predictions indicating the tree age at which its stem diameter would be restriced by tree apparel. By the application of the allometric results (Table 2) to apparel (Figure 1) the designer could increase longevity of intended hard landscapes and trees (Stoffberg, 2006).

Table 2. The mean estimated tree age in years $(y)$ of three street tree species presented in $50 \mathrm{~mm}$ diameter increments for application to apparel (Stoffberg, 2006).

\begin{tabular}{|c|c|c|c|c|c|c|c|c|c|c|c|c|c|}
\hline \multirow{2}{*}{ Species } & \multicolumn{13}{|c|}{ Tree ring, grate and grid sizes at $50 \mathrm{~mm}$ stem diameter $(\emptyset)$ increments } \\
\hline & $300 \emptyset$ & $350 \emptyset$ & $400 \emptyset$ & $450 \emptyset$ & $500 \emptyset$ & $550 \emptyset$ & $600 \emptyset$ & $650 \emptyset$ & $700 \emptyset$ & $750 \emptyset$ & $800 \emptyset$ & $850 \emptyset$ & $900 \emptyset$ \\
\hline $\begin{array}{l}\text { C. } \\
\text { erythr. }\end{array}$ & $10.75 y$ & $12.75 y$ & $15 y$ & $17.25 y$ & $19.75 y$ & $22.25 y$ & $25.25 y$ & $28.25 y$ & $31.25 y$ & $34.75 y$ & $38.25 y$ & $42.00 y$ & $46.00 y$ \\
\hline $\begin{array}{l}\text { S. } \\
\text { pend. }\end{array}$ & $13.50 y^{\#}$ & - & - & - & - & - & - & - & - & - & - & - & - \\
\hline
\end{tabular}

The stratified random sampling of trees represents various ages, planting locations and different environmental conditions within the City of Pretoria. The results are therefore representative of a variety of climate and environmental zones, rendering them applicable to a reasonably wider range of environments (Stoffberg, 2006).

Figure 1 presents the research results applied to tree rings manufactured by Vanstone, South Africa (http://www.vanstone.co.za/node/161, accessed July 22, 2014). Combretum erythrophyllum would outgrow all the apparel in the product range presented in this paper. Combretum erythrophyllum reaches the largest estimated mean stem diameter of $919 \mathrm{~mm}$ at an age of 47.50 years. However, the estimated upper confidence level is $1000 \mathrm{~mm}$ at age 37.75 years and a maximum estimated upper confidence level of $1175 \mathrm{~mm}$ is reached at 47.50 years, which is also the oldest data point for this study (Stoffberg, 2006). 


\begin{tabular}{|c|c|c|}
\hline Image of tree ring & Tree ring type & Years \\
\hline & $\begin{array}{l}\text { Pavement Tree Ring - half } \\
\text { Inside diam: } 600 \mathrm{~mm}\end{array}$ & 25.25 \\
\hline & $\begin{array}{l}550 \mathrm{~mm} \text { Tree Ring - full } \\
\text { Inside diam: } 470 \mathrm{~mm}\end{array}$ & 18.25 \\
\hline & $\begin{array}{l}460 \mathrm{~mm} \text { Tree Ring - full } \\
\text { Inside diam: } 350 \mathrm{~mm}\end{array}$ & 12.75 \\
\hline & $\begin{array}{l}\text { Ribbed Tree Ring - full } \\
\text { Inside diam: } 600 \mathrm{~mm}\end{array}$ & 25.25 \\
\hline & $\begin{array}{l}\text { Ribbed Tree Ring - half } \\
\text { Inside diam: } 600 \mathrm{~mm}\end{array}$ & 25.25 \\
\hline & $\begin{array}{l}\text { Small Ribbed Tree Ring - } \\
\text { full } \\
\text { Inside diam: } 470 \mathrm{~mm}\end{array}$ & 18.25 \\
\hline & $\begin{array}{l}\text { Square Rope Tree Ring - } \\
\text { full }\end{array}$ & 20.75 \\
\hline & Inside: 520 x520mm & \\
\hline
\end{tabular}

Figure 1. The tree rings manufactured by Vanstone, South Africa (http://www.vanstone.co.za/node/161, accessed July 22, 2014) and the tree age at which Combretum erythrophyllum will reach the same or larger inside diameter.

\section{CONCLUSIONS}

The application of the findings could improve designing of hard landscapes, infrastructure investments, maintenance programs, reduce costly repairs associated with apparel and prevent potential trip and fall incidents.

Limited information is available on savannah and other indigenous species' stem diameter growth in an urban setting, which renders significance to the presented research. Research to extend timeframes and increase a larger diversity of indigenous species will optimise the variety of choice.

This study illustrates that applied quantitative research should be considered in landscape design. Furthering quantitative research is thus recommended, especially in the 
context that South Africa is a developing and emerging world country.

\section{ACKNOWLEDGEMENTS}

Afrox, the Bradlows Foundation, the National Research Foundation (Grant no. 2053522) and the University of South Africa (Unisa) provided financial supported for this research. These funders are gratefully acknowledged.

\section{Literature cited}

Bentsen, P., Lindholst, A.C., and Konijnendijk, C.C. (2010). Reviewing eight years of Urban Forestry \& Urban Greening: taking stock, looking ahead. Urban For. Urban Green. 9 (4), 273-280 http://dx.doi.org/10.1016/j.ufug. 2010.06.003.

Brewer, J.A., Burns, P.Y., and Cao, Q.V. (1985). Short term projection accuracy of five asymptotic height-age curves for Loblolly pine. For. Sci. 31, 414-418.

Clark, D.B., and Clark, D.A. (2000). Landscape-scale variation in forest structure and biomass in a tropical rain forest. For. Ecol. Manage. 137 (1-3), 185-198 http://dx.doi.org/10.1016/S0378-1127(99)00327-8.

De Lacy, P., and Shackleton, C.M. (2014). The comparative growth rates of indigenous street and garden trees in Grahamstown, South Africa. S. Afr. J. Bot. 92, 94-96 http://dx.doi.org/10.1016/j.sajb.2014.02.007.

du Toit, S.H.C. (1979). Analysis of growth curves. Ph.D. Thesis (Pretoria, South Africa: University of South Africa).

Gaugris, J.Y., Van Rooyen, J.M.W., and du Bothma, P. (2008). Growth rate of selected woody species in northern Maputaland, KwaZulu-Natal, South Africa. SA J. Bot. 74, 85-92.

Jalota, R.K., and Sangha, K.K. (2000). Comparative ecological-economical analysis of growth performance of exotic Eucalyptus tereticornis and indigenous Dalbergia sissoo in mono-culture plantations. Ecol. Econ. 33 (3), 487-495 http://dx.doi.org/10.1016/S0921-8009(00)00133-6.

Jorgensen, A., Hitchmough, J., and Calvert, T. (2002). Woodland spaces and edges: their impact on perception of safety and preference. Landsc. Urban Plan. 60 (3), 135-150 http://dx.doi.org/10.1016/S0169-2046(02)00052-X.

Jorgensen, A., Hitchmough, J., and Dunnett, N. (2007). Woodland as a setting for housing-appreciation and fear and the contribution to residential satisfaction and place identity in Warrington New Town, UK. Landsc. Urban Plan. 79 (3-4), 273-287 http://dx.doi.org/10.1016/j.landurbplan.2006.02.015.

Lehmann, S. (2014). Low carbon districts: mitigating the urban heat island with green roof infrastructure. City. Cult. Sc. 5, 1-8.

McPherson, E.G., and Peper, P.J. (2012). Urban tree growth modeling. Arboriculture \& Urban Forestry 38 (5), 172180.

McPherson, E.G., Nowak, D.J., and Rowntree, R.A. (1994). Chicago's Urban Forest Ecosystem: Results of the Chicago Urban Forest Climate Project. General Technical Report NE-186.

Miller, R.W. (1997). Urban Forestry. Planning and Managing Urban Greenspaces (New Jersey, USA: University of Wisconsin, Prentice Hall).

Nowak, D.J., and Dwyer, J.F. (2007). Understanding the benefits and costs of urban forest ecosystems. In Urban and Community Forestry in the Northeast, $2^{\text {nd }}$ edn, J.E. Kuser, ed. (New York, USA: Springer), p.25-41.

Peper, P.J., McPherson, E.G., and Mori, S.M. (2001a). Equations for predicting diameter, height, crown width and leaf area of San Joaquin Valley street trees. Journal of Arboriculture 27, 306-317.

Peper, P.J., McPherson, E.G., and Mori, S.M. (2001b). Predictive equations for dimensions and leaf area of coastal Southern California street trees. Journal of Arboriculture 27, 169-181.

Roy, S., Byrne, J., and Pickering, C. (2012). A systematic quantitative review of urban tree benefits, costs, and assessment methods across cities in different climatic zones. Urban For. Urban Green. 11 (4), 351-363 http://dx. doi.org/10.1016/j.ufug.2012.06.006.

Shackleton, C.M., Hebinck, P., Kaoma, H., Chishaleshale, M., Chinyimba, A., Shackleton, S.E., Gambiza, J., and Gumbo, D. (2014). Low-cost housing developments in South Africa miss the opportunities for household level urban greening. Land Use Policy 36, 500-509 http://dx.doi.org/10.1016/j.landusepol.2013.10.002.

Soares, A.L., Rego, F.C., McPherson, E.G., Simpson, J.R., Peper, P.J., and Xiao, Q. (2011). Benefits and costs of street trees in Lisbon, Portugal. Urban For. Urban Green. 10 (2), 69-78 http://dx.doi.org/10.1016/j.ufug.2010.12.001.

Stoffberg, G.H. (2006). Growth and carbon sequestration by street trees in the City of Tshwane, South Africa. Ph.D. thesis (Pretoria, South Africa: University of Pretoria). 
Stoffberg, G.H., and van Rooyen, M.W. (2012). An international perspective on growth rate and carbon sequestration of trees used in the urban landscape. In South African Landscape Architecture, A. Reader, G.H. Stoffberg, C. Hindes, and L. Muller, eds. (Pretoria, South Africa: Unisa Press), p.143-148.

Stoffberg, G.H., van Rooyen, M.W., van der Linde, M.J., and Groeneveld, H.T. (2008). Predicting the growth in tree height and crown size of three street tree species in the City of Tshwane, South Africa. Urban For. Urban Green. 7 (4), 259-264 http://dx.doi.org/10.1016/j.ufug.2008.05.002.

Stoffberg, G.H., van Rooyen, M.W., van der Linde, M.J., and Groeneveld, H.T. (2010). Carbon sequestration estimates of indigenous street trees in the City of Tshwane, South Africa. Urban For. Urban Green. 9 (1), 9-14 http://dx.doi.org/10.1016/j.ufug.2009.09.004.

Van Wyk, B., and Van Wyk, P. (2013). Field Guide to Trees of Southern Africa (Cape Town, South Africa: Struik Publishers), pp.732.

Vanstone Precast (Pty) Ltd Pretoria P.0 Box 911-081 Rosslyn 0200. (http://www.vanstone.co.za/node/161).

Zhang, L. (1997). Cross-validation of non-linear growth functions for modelling tree height-diameter relationships. Ann. Bot. (Lond.) 79 (3), 251-257 http://dx.doi.org/10.1006/anbo.1996.0334. 